\title{
PENGARUH MODEL PEMBELAJARAN KOOPERATIF THINK TALK WRITE TERHADAP PEMAHAMAN KONSEP MATEMATIKA SISWA SMP
} WRITE OF THE MATHEMATICAL CONCEPT IN THE MIDDLE SCHOOL)

\author{
Anggi Rahmani ${ }^{1}$, Hadi Sutiawan ${ }^{2}$ \\ ${ }^{1}$ STKIP Setia Budhi Rangkasbitung, anggi.rahmani@stkipsetiabudhi.ac.id \\ ${ }^{2}$ STKIP Setia Budhi Rangkasbitung, hadi.sutiawan@stkipsetiabudhi.ac.id
}

\begin{abstract}
Abstrak
Penelitian ini bertujuan untuk mengetahui pengaruh model pembelajarankooperatif tipe think talk write terhadap kemampuan pemahaman konsep matematika siswa SMP. Penelitian ini dilakukan di SMP Negeri 1 Kragilan. Metode yang digunakan dalam penelitian ini adalah quasi eksperimen. Teknik pengumpulan data yaitu tes pemahaman konsep matematika. Hasil penelitian menunjukkan bahwa (1) Pencapaian akhir kemampuan pemahaman konsep matematika siswa yang mendapatkan model pembelajaran think talk write lebih tinggi daripada siswa yang mendapatkan model pembelajaran ekspositori; (2) Peningkatan kemampuan pemahaman konsep matematika siswa yang mendapatkan model pembelajaran think talk write, lebih tinggi siswa yang mendapatkan daripada siswa yang mendapatkan model pembelajaran ekspositori.
\end{abstract}

Kata kunci: Pemahaman Konsep, Think Talk Write

\begin{abstract}
This study aims to determine the effect of think talk write cooperative learning models on the ability to understand mathematics concepts of junior high school students. This research was conducted at SMP Negeri 1 Kragilan. The method used in this research is quasi-experimental. Data collection techniques are understand mathematics concepts tests. The results showed that (1) The final achievement of the ability to understand mathematical concepts of students who get a think talk write learning model is higher than students who get an expository learning model; (2) Increasing the ability to understand mathematical concepts of students who get the think talk write learning model, higher students who get than students who get expository learning models.
\end{abstract}

Keywords: Think Talk Write, Understand Mathematical Concepts 


\section{PENDAHULUAN}

Kemampuan pemahaman konsep matematika siswa Indonesia dapat diketahui dari hasil survei kemampuan yang dilakukan oleh Programme for International Student Assessment (PISA) pada tahun 2018 dan The Trends in International Mathematics and Science Study (TIMSS) pada tahun 2015. TIMSS dan PISA merupakan dua lembaga dunia yang menyelenggarakan tes yang salah satunya ditujukan untuk pelajar tingkat SMP yang telah dipilih secara acak dari tiap Negara. Berdasarkan data dari Organisation for Economic Co-operation and Development (OECD)PISA 2018 diikuti oleh 79 negara, sedangkan data International Association for the Evaluation of Educational Achievement (IEA)TIMSS 2015 diikuti oleh 49 negara.

Hasil PISA 2018menunjukkan bahwa skor rata-rata matematika siswa Indonesia adalah 379, dengan rata-rata internasional sebesar 487. PISA bertujuan untuk mengukur kemampuan matematis, yang didefinisikan sebagai kemampuan siswa untuk merumuskan, menggunakan dan menginterpretasikan matematika dalam berbagai konteks matematika, yaitu meliputi penalaran secara matematis dan penggunaan konsep matematis, prosedur, fakta, alat untuk menggambarkan, menjelaskan dan memprediksi fenomena. Perbandingan tingkat kecakapan matematis siswa Indonesia dengan siswa Thailand pada PISA 2018 dapat dilihat pada gambar berikut:

\begin{tabular}{|c|c|c|c|c|c|c|c|}
\hline & Di bawah Level 1 & Level 1 & Level 2 & Level 3 & Level 4 & Level 5 & Level 6 \\
\hline Indonesia & 37,9 & 30,7 & 19,6 & 8,4 & 2,7 & 0,6 & 0,1 \\
\hline Thailand & 24,2 & 29,6 & 26,1 & 13,8 & 4,8 & 1,2 & 0,2 \\
\hline Korea & 5,4 & 10,0 & 17,2 & 23,7 & 22,7 & 14,3 & 6,6 \\
\hline Jepang & 2,9 & 7,8 & 17,2 & 25,8 & 25,9 & 15,0 & 5,3 \\
\hline Hong Kong & 2,5 & 6,4 & 13,6 & 23,4 & 27,4 & 18,8 & 7,7 \\
\hline OECD (rata-rata) & 8,5 & 14,9 & 22,5 & 24,8 & 18,6 & 8,4 & 2,3 \\
\hline
\end{tabular}

Gambar 1. Perbandingan Tingkat Kecakapan Matematis

(Susanti, 2017)

Siswa Indonesia dengan Siswa Thailand

Gambar di atas menunjukkan bahwa kemampuan kecakapan matematis sebagian besar siswa Indonesia berada di level 1, artinya siswa Indonesia hanya mampu menyelesaikan soal matematika pada konteks yang sederhana. Mereka akan menemui kesulitan ketika menghadapi soal-soal yang lebih rumit.

Hasil TIMSS 2015menyebutkan bahwa skor rata-rata matematika siswa Indonesia adalah 397, dengan rata-rata skor internasional 500. Salah satu dari standar interasional TIMSS 2015 mengenai prestasi matematika, yaitu siswa dapat mengaplikasikan pemahaman dan pengetahuan mereka dalam berbagai situasi yang kompleks. hasil TIMSS 2015 juga menunjukkan kinerja siswa Indonesia lebih rendah dibandingkan dengan kinerja siswa Thailand dan nilai international median pada standar internasional TIMSS 2015, hanya sekitar 43\% siswa Indonesia yang memenuhi low benchmark. Perbandingan kinerja (performance) siswa Indonesia dengan siswa Thailand pada TIMSS 2015 dapat dilihat pada Tabel 1 berikut: 
Tabel 1. Perbandingan Presentase Pencapaian Siswa Indonesia dan Thailand pada TIMSS 2015 Mengenai Presentasi Matematika kelas 8

\begin{tabular}{lllll}
\hline Level & $\begin{array}{l}\text { Advance } \\
\text { Benchmark } \\
(\mathbf{6 2 5})\end{array}$ & $\begin{array}{l}\text { High } \\
\text { Benchmark } \\
\mathbf{( 5 5 0 )}\end{array}$ & $\begin{array}{l}\text { Intermediate } \\
\text { Benchmark } \\
\mathbf{( 4 7 5 )}\end{array}$ & $\begin{array}{l}\text { Low } \\
\text { Benchmark } \\
\mathbf{( 4 0 0 )}\end{array}$ \\
\hline Negara & $0 \%$ & $2 \%$ & $15 \%$ & $43 \%$ \\
\hline Indonesia & $2 \%$ & $8 \%$ & $28 \%$ & $62 \%$ \\
\hline $\begin{array}{l}\text { Thternational } \\
\text { Median }\end{array}$ & $3 \%$ & $17 \%$ & $46 \%$ & $75 \%$ \\
\hline
\end{tabular}

(Hadi \& Novaliyosi, 2019)

Menurut Auliya (2013) beberapa faktor penyebab dari rendahnya kemampuan pemahaman matematika siswa Indonesia, antara lain siswa terbiasa mempelajari konsep-konsep dan rumus-rumus matematika dengan cara menghafal tanpa memahami maksud, isi dan kegunaannya.Mereka hanya fokus pada keterampilan berhitungan seperti penjumlahan, pengurangan, perkalian dan pembagian sejumlah bilangan. Faktor lainnya, yaitu kebanyakan siswa memahami konsep matematika yang baru tanpa didasari pemahaman mengenai konsep matematika sebelumnya. Kondisi tersebut bertentangan dengan hakikat matematika, yaitu bahwa matematika merupakan suatu ilmu yang hirarki, dimana terdapat keterkaitan antara satu konsep dengan konsep lainnya.Lestari dan Yudhanegara (2015: 81) menyatakan bahwa kemampuan pemahaman konsep matematika adalah kemampuan yang berkenaan dengan memahami ide-ide matematika yang menyeluruh dan fungsional.

Dengan diberlakukannya kurikulum 2013 revisi di sekolah-sekolah menuntut siswa untuk bersikap aktif, kreatif dan inovatif dalam mengikuti setiap proses pembelajaran. Menurut Yamin dan Ansari(2012) Salah satu upaya untuk membangun kemampuan pemahaman konsep matematika siswa adalah melalui penerapan pembelajaran yang tepat, yang salah satunya yaitu dengan menerapkan pembelajaran matematika dengan menggunakan pembelajaran kooperatif tipe Think-Talk-Write (TTW). Model pembelajaran yang digunakan ini mengharuskan siswa terlibat berpikir, berbicara, dan menulis dalam proses pembelajaran yang terbentuk dalam pengelompokan secara heterogen dengan anggota 3-4 siswa. Huiker dan Laughlin (1996) sebagai orang-orang yang memperkenalkan tipe pembelajaran ini menyebutkan bahwa penerapan TTW memungkinkan seluruh siswa mengemukakan ide-ide pemikirannya, membangun secara tepat untuk berfikir dan refleksi, mengorganisasikan ide-ide, serta mengetes ide tersebut sebelum siswa diminta untuk menulis.

Pada tahap think, siswa membaca teks berupa soal (kalau memungkinkan dimulai dengan soal yang berhubungan dengan permasalahan sehari-hari atau kontekstual). Selanjutnya tahap talk, siswa diberi kesempatan untuk membicarakan hasil penyelidikan pada tahap think. Tahap terakhir yaitu write, 
pada tahap ini siswa menuliskan ide-ide yang diperolehnya dan kegiatan tahap think dan tahap talk. Tulisan ini terdiri atas landasan konsep yang digunakan, keterkaitan dengan materi sebelumnya, strategi penyelesaian, dan solusi yang diperoleh.Berdasarkan dengan uraian tersebut, maka akan diteliti apakah model pembelajaran kooperatif tipe think talk write berpengaruh terhadap kemampuan pemahaman konsep matematika.

\section{KAJIAN TEORI}

\section{Model Pembelajaran Kooperatif Tipe Think Talk Write}

Model pembelajaran kooperatif tipe think talk write diperkenalkan oleh Huinker \& Laughlin (1996). Pada dasarnya pembelajaran ini dibangun melalui proses berpikir, berbicara dan menulis. Pembelajaran kooperatif tipe TTW dapat menumbuh kembangkan kemampuan pemahaman konsep matematika (Yamin dan Ansari, 2012). Alur kemajuan pembelajaran think talk write dimulai dari keterlibatan siswa dalam berpikir atau berdialog dengan dirinya sendiri setelah proses membaca, selanjutnya berbicara dan membagi ide dengan temannya sebelum menulis.

Suasana ini lebih efektif jika dilakukan dalam kelompok heterogen dengan 3-5 siswa. Dalam kelompok ini siswa diminta membaca, membuat catatan kecil, menjelaskan, mendengarkan dan membagi ide bersama teman kemudian mengungkapkannya melalui tulisan. Aktivitas berpikir, berbicara dan menulis ini adalah salah satu bentuk aktivitas belajar mengajar yang memberikan peluang kepada siswa untuk berpartisipasi aktif. Tahapan-tahapan yang dilakukan dalam pembelajaran menggunakan tipe ini adalah berpikir (Think), berbicara (Talk), dan menulis (Write).

\section{Think}

Aktivitas berpikir dalam pembelajaran, terdapat dalam kegiatan yang dapat memancing siswa untuk memikirkan sebuah permasalahan baik dalam eksperimen, kegiatan demonstrasi yang dilakukan oleh guru atau siswa, pengamatan gejala fisis atau berbagai peristiwa dalam kehidupan sehari-hari. Aktivitas berpikir dapat dilihat dari proses membaca suatu teks Matematika atau berisi cerita Matematika kemudian membuat catatan apa yang telah dibaca. Proses membaca buku paket atau handout matematika serta berbagai macam artikel yang berhubungan dengan pokok bahasan. Setelah itu siswa mulai memikirkan solusi dari permasalahan tersebut dengan cara menuliskannya di buku catatan atau handout atau pun mengingat bagian yang dipahami serta yang tidak dipahaminya.

Menurut Wiederhold (1997) membuat catatan berarti menganalisis tujuan isi teks dan memeriksa bahan-bahan yang ditulis. Membuat catatan mempertinggi pengetahuan siswa bahkan meningkatkan keterampilan berpikir dan menulis. Salah satu manfaat dari proses ini adalah membuat catatan akan menjadi bagian integral dalam setting pembelajaran.

\section{Talk}

Siswa melakukan komunikasi dengan teman menggunakan kata-kata dan bahasa yang mereka pahami. Siswa menggunakan bahasa untuk menyajikan ide kepada temannya, membangun teori bersama, sharing strategi solusi dan membuat definisi. Talking membantu guru mengetahui tingkat pemahaman siswa dalam belajar sehingga dapat mempersiapkan perlengkapan pembelajaran yang dibutuhkan. Fase berkomunikasi (talk) ini juga memungkinkan siswa untuk 
terampil berbicara. Secara alami dan mudah proses komunikasi dapat dibangun di kelas dan dimanfaatkan sebagai alat sebelum menulis. Selain itu, berkomunikasi dalam suatu diskusi dapat membantu kolaborasi dan meningkatkan aktivitas belajar dalam kelas. Selanjutnya, berbicara baik antar siswa maupun dengan guru dapat meningkatkan pemahaman. Hal ini bisa terjadi karena saat siswa diberi kesempatan untuk berbicara atau berdialog, sekaligus merekonstruksi berbagai ide untuk dikemukakan melalui dialog.

Tahap berbicara yaitu berkomunikasi dengan menggunakan kata-kata dan bahasa yang siswa pahami. Dalam matematika tahap "Talk" penting. Hal ini dikarenakan:

a. Apakah itu tulisan, gambaran, isyarat, atau percakapan merupakan perantara ungkapan matematika sebagai bahasa manusia,

b. Pemahaman matematik dibangun melalui interaksi dan konversasi (percakapan) antara sesama individual yang merupakan aktivitas sosial yang bermakna,

c. Cara utama partisipasi komunikasi dalam matematika adalah melalui "talk",

d. Pembentukan ide (forming ideas) melalui proses talking,

e. Internalisasi ide (internalizing ideas),

f. Meningkatkan dan menilai kualitas berpikir. Talking membantu guru mengetahui tingkat pemahaman siswa dalam belajar matematika, sehingga dapat mempersiapkan perlengkapan pembelajaran yang dibutuhkan.

\section{Write}

Siswa menuliskan hasil diskusi atau dialog pada lembar kerja yang disediakan. Aktivitas menulis berarti merekonstruksi ide, karena setelah berdiskusi atau berdialog antar teman dan kemudian mengungkapkannya melalui tulisan. Aktivitas menulis akan membantu siswa dalam membuat hubungan dan juga memungkinkan guru melihat pengembangan konsep siswa. Menurut Yamin dan Ansari (2012) aktivitas siswa selama fase ini adalah:

a. Menulis solusi terhadap masalah atau pertanyaan yang diberikan termasuk perhitungan,

b. Mengorganisasikan semua pekerjaan langkah demi langkah baik penyelesaiannya ada yang menggunakan diagram, grafik, atau pun tabel agar mudah dibaca dan ditindaklanjuti,

c. Mengoreksi semua pekerjaan sehingga yakin tidak ada pekerjaan atau pun perhitungan yang ketinggalan,

d. Meyakini bahwa pekerjaannya yang terbaik yaitu lengkap, mudah dibaca dan terjamin keasliannya.

Langkah-langkah pembelajaran dengan tipe TTW menurut Yamin dan Ansari (2012) adalah sebagai berikut:

a. Guru membagi teks bacaan berupa Lembar Diskusi Siswa (LDS) yang memuat situasi masalah dan petunjuk serta prosedur pelaksanaannya,

b. Siswa membaca teks dan membuat catatan dari hasil bacaan secara individual untuk dibawa ke forum diskusi (think),

c. Siswa berinteraksi dan berkolaborasi dengan teman untuk membahas isi catatan (talk). Guru berperan sebagai mediator lingkungan belajar, siswa mengkontruksi sendiri pengetahuan sebagai hasil kolaborasi (write).

\section{Pemahaman Konsep Matematika}


Lestari dan Yudhanegara (2015) menyatakan bahwa kemampuan pemahaman konsep matematika adalah kemampuan yang berkenaan dengan memahami ide-ide matematika yang menyeluruh dan fungsional. Adapun indikator-indikator kemampuan pemahaman konsep matematika, yaitu:

a. Menyatakan ulang konsep yang telah dipelajari

b. Mengklarifikasi objek-objek berdasarkan konsep matematika

c. Menerapkan konsep secara algoritma

d. Memberikan contoh dan bukan contoh dari konsep yang dipelajari

e. Menyajikan konsep dalam berbagai representasi, dan

f. Mengaitkan berbagai konsep matematika secara internal.

Polya (Sumarmo, 2012: 6) merinci kemampuan pemahaman pada empat tingkat yaitu:

a. Pemahaman mekanikal yang dicirikan oleh mengingat dan menerapkan rumus secara rutin dan menghitung secara sederhana. Kemampuan ini tergolong pada kemampuan tingkat rendah.

b. Pemahaman induktif yang dicirikan oleh menerapkan rumus atau konsep dalam kasus sederhana atau dalam kasus serupa. Kemampuan ini tergolong pada kemampuan tingkat rendah.

c. Pemahaman rasional yang dicirikan oleh membuktikan kebenaran suatu rumus dan teorema. Kemampuan ini tergolong pada kemampuan tingkat tinggi.

d. Pemahaman intuitif yang dicirikan oleh memperkirakan kebenaran dengan pasti (tanpa ragu-ragu) sebelum menganalisis lebih lanjut. Kemampuan ini tergolong pada kemampuan tingkat tinggi.

NCTM (2000) menyatakan bahwa untuk mencapai pemahaman yang bermakna maka pembelajaran matematika harus diarahkan pada pengembangan kemampuan koneksi matematik antar berbagai ide, memahami bagaimana ide-ide matematik saling terkait satu sama lain sehingga terbangun pemahaman menyeluruh, dan menggunakan matematik dalam konteks di luar matematika. Pemahaman konsep matematika merupakan landasan penting untuk berpikir dalam menyelesaikan permasalahan matematika maupun permasalahan seharihari. Berdasarkan uraian di atas, pemahaman konsep matematika dalam penelitian ini diukur dengan mengacu pada indikator-indikator berikut:

a. Kemampuan menyatakan ulang suatu konsep.

b. Kemampuan melakukan penggolongan objek-objek menurut sifat-sifat tertentu sesuai dengan konsepnya.

c. Kemampuan menyajikan konsep dalam bentuk lain seperti simbol, gambar, diagram, tabel, dan lain-lain.

d. Kemampuan mengaplikasikan konsep/algoritma dalam suatu permasalahan.

e. Kemampuan mengaitkan suatu konsep dengan konsep lainnya.

\section{METODE}

Penelitian ini merupakan penelitian kuasi eksperimen dengan variabel bebas, yaitu model pembelajarankooperatif tipe think talk write, dan variabel terikat yaitu kemampuan pemahaman konsep matematikasiswa pada pokok bahasan penyajian data. Populasi pada penelitian ini adalah seluruh siswa SMP Negeri Se-Kecamatan Kragilan tahun pelajaran 2018/2019. Populasi target pada penelitian ini yaitu seluruh siswa SMP Negeri 1 Kragilan dan populasi 
terjangkaunya seluruh siswa kelas VIII SMP Negeri 1 Kragilan. Pengambilan sampel dilakukan dengan teknik cluster random sampling.

Pengambilan sampel dapat diuraikan sebagai berikut: (1) menentukan SMP Negeri di Kecamatan Kragilan dengan Akreditasi A sebagai populasi penelitian; (2) memilih secara random sampling SMP Negeri di Kecamatan Kragilan dengan akreditasi A, sehingga terpilih yaitu SMP Negeri 1 Kragilan sebagai populasi target;(3) mengidentifikasi seluruh siswa SMP Negeri 1 Kragilan dan menentukan populasi terjangkau yaitu seluruh siswa kelas VIII SMP Negeri 1 Kragilan tahun ajaran 2018/2019. Selanjutnya melakukan uji prasyarat yaitu uji normalitas dan uji homogenitas, kemudian uji kesamaan rata-rata untuk menguji kesetaraan sampel penelitian dengan menggunakan nilai UASmatematika semester ganjil. siswa kelas VIII SMP Negeri 1 Kragilan terdiri dari 9 rombongan belajar.

\section{HASIL DAN PEMBAHASAN}

Dalam penelitian ini diperoleh data hasil pretes, postes, dan gain yang menunjukan tentang peningkatan kemampuan pemahaman matematika siswa. Data-data yang diperoleh berasal dari penelitian yang dilaksanakan di salah satu SMP Negeri di kabupaten Serang pada tahun ajaran 2018/2019. Metode penelitian yang digunakan adalah metode kuasi eksperimen dengan sampel yang digunakan dalam penelitian ini yaitu dua kelas yang dipilih secara acak dari 9 kelas VII yang ada. Terpilih kelas VIII C sebagai kelas eksperimen dengan jumlah siswa sebanyak 32 siswa dan kelas VIII D sebagai kelas kontrol dengan jumlah siswa sebanyak 31 siswa. Materi yang diajarkan yaitu kubus dan balok.

Data mengenai kemampuan pemahaman konsep matematika diperoleh dari hasil pretes dan postes pada masing-masing kelas yang disajikan dalam tabel dibawah ini.

Tabel 2. Statistik Deskriptif Data Pretes, Postes, dan Gain

\begin{tabular}{c|cccccc}
\hline \multirow{2}{*}{ Kelas } & \multicolumn{3}{|c|}{ Eksperimen } & \multicolumn{3}{c}{ Kontrol } \\
\cline { 2 - 7 } & Pretes & Postes & Gain & Pretes & Postes & Gain \\
\hline Skor Ideal & 37 & 37 & 1 & 37 & 37 & 1 \\
\hline Rata-rata & 13,25 & 24,38 & 0,47 & 11,08 & 18,68 & 0,34 \\
\hline Varians & 25,23 & 26,30 & 0,032 & 22,99 & 49,89 & 0,033 \\
\hline Standar Deviasi & 5,02 & 5,13 & 0,18 & 4,79 & 7,06 & 0,18 \\
\hline Skor Tertinggi & 25 & 34 & 0,79 & 22 & 33 & 0,85 \\
\hline Skor Terendah & 5 & 15 & 0,10 & 3 & 7 & 0,04 \\
\hline
\end{tabular}

Berdasarkan tabel di atas, hasil analisis data pretes kelas eksperimen dari 32 siswa diperoleh skor tertinggi 25 dan skor terendah 5. Pada kelas kontrol dengan siswa sebanyak 31 siswa diperoleh skor tertinggi 22dan skor terendah 3. Sementara itu, hasil analisis data postes kelas eksperimen diperoleh skor tertinggi 34 dan skor terendah 15. Sedangkan pada kelas kontrol diperoleh skor tertinggi 33 dan skor terendah 7 .

\section{Uji Normalitas}

Pengujian normalitas untuk data pretes, postes, dan gain kemampuan pemahaman konsep matematika untuk kelas eksperimen atau kelas kontrol 
digunakan rumus Chi-Kuadrat $\left(\chi^{2}\right)$. Uji normalitas dilakukan untuk mengetahui apakah sebaran data berasumsi normal atau tidak.

Tabel 3. Uji Normalitas Data Pretes, Postes, dan Gain Kemampuan Pemahaman Konsep Matematika

\begin{tabular}{c|ccc}
\hline Jenis Data & Uji Statistik $\left(\chi^{2}\right)$ & Eksperimen & Kontrol \\
\hline \multirow{4}{*}{ Pretes } & $\chi_{\text {hitung }}^{2}$ & 6,45 & 7,84 \\
\cline { 2 - 4 } & $\mathrm{dk}$ & 5 & 4 \\
\cline { 2 - 4 } & $\chi_{\text {tabel }}^{2}$ & 11,070 & 9,488 \\
\hline \multirow{4}{*}{ Postes } & $\chi_{\text {hitung }}^{2}$ & 4,78 & 3,99 \\
\cline { 2 - 4 } & $\mathrm{dk}$ & 4 & 5 \\
\cline { 2 - 4 } & $\chi_{\text {tabel }}^{2}$ & 9,488 & 11,070 \\
\hline \multirow{4}{*}{ Gain } & $\chi_{\text {hitung }}^{2}$ & 1,84 & 2,33 \\
\cline { 2 - 4 } & $\mathrm{dk}$ & 5 & 5 \\
\cline { 2 - 4 } & $\chi_{\text {tabel }}^{2}$ & 11,070 & 11,070 \\
\hline
\end{tabular}

Berdasarkan Tabel 3 di atas, untuk $\alpha=0,05$ dengan kriteria $\chi_{\text {hitung }}^{2}<\chi_{\text {tabel }}^{2}$ diasumsikan data berdistribusi normal. Jika terjadi sebaliknya maka asumsi data tidak berdistribusi normal. Sesuai dengan kriteria tersebut, dapat disimpulkan bahwa data pretes, postes, dan gain kemampuan pemahaman konsep matematika kelas eksperimen dan kelas kontrol berdistribusi normal.

\section{Uji Homogenitas}

Setelah uji normalitas, uji prasyarat berikutnya yaitu uji homogenitas. Uji homogenitas digunakan untuk menganalisis suatu data, terkait apakah data tersebut berasal dari populasi yang variansinya sama (homogen) atau tidak. Data dalam penelitian ini yang di uji homogenitasnya meliputi data pretes, data postes, dan data gain kemampuan pemahaman konsep matematika. Uji yang digunakan yaitu uji-F dengan membandingkan varians terbesar dan varians terkecil.

Tabel 4. Uji Homogenitas Data Pretes, Postes, dan Gain Kemampuan Pemahaman Konsep Matematika

\begin{tabular}{cccc}
\hline Keterangan & Pretes & Postes & Gain \\
\hline $\mathrm{F}_{\text {hitung }}$ & 1,10 & 1,09 & 1,03 \\
\hline dk pembilang & 31 & 30 & 30 \\
\hline dk penyebut & 30 & 31 & 31 \\
\hline $\mathrm{F}_{\text {tabel }}$ & 1,83 & 1,83 & 1,83 \\
\hline Kesimpulan & Homogen & Homogen & Homogen \\
\hline
\end{tabular}


Untuk $\alpha=0,05$ dengan kriteria jika $\mathrm{F}_{\text {hitung }}<\mathrm{F}_{\text {tabel }}$ maka data homogen. Jika terjadi sebaliknya maka data tidak homogen. Berdasarkan tabel 4 diatas, data pretes, postes, dan gain homogen.

\section{Uji Perbedaan Dua Rata-Rata}

Uji prasyarat yang sudah dilakukan sebelumnya, diperoleh data pretes, postes dan gain kemampuan pemahaman konsep matematika kelas eksperimen dan kelas kontrol berdistribusi normal dan homogen. Analisis dapat dilanjutkan dengan uji perbedaan dua rata-rata untuk menguji hipotesis yang sudah dibuat. Uji perbedaan dua rata-rata yang digunakan untuk data pretes, postes, dan gain kemampuan pemahaman konsep matematika yaitu uji- $t$ dengan taraf signifikansi $\alpha=0,05 \mathrm{dan} \mathrm{dk}=61$.

Data pretes dianalisis untuk mengetahui apakah terdapat perbedaan yang signifikan kemampuan pemahaman konsep matematika siswa antara kelas eksperimen dan kelas kontrol sebelum diberikan pembelajaran. Uji perbedaan dua rata-rata yang digunakan yaitu uji- $t$ dua pihak. Pada tabel $t$ menunjukkan bahwa $t_{\text {tabel }}$ dengan $\mathrm{dk}=61$ untuk uji dua pihak adalah 1,999, sedangkan nilai $t_{\text {hitung }}$ didapat sebesar 1,75. Karena $-t_{\text {tabel }} \leq t_{\text {hitung }} \leq t_{\text {tabel }}$ atau $-1,999 \leq 1,75 \leq 1,999$ maka $\mathrm{H}_{0}$ diterima, sehinggga diperoleh bahwa tidak terdapat perbedaan kemampuan awal pemahaman konsep matematika siswa antara kelas eksperimen dan kelas kontrol.

Uji prasyarat sebelumnya menyatakan bahwa data postes kedua kelas berdistribusi normal dan homogen. Uji perbedaan dua rata-rata yang digunakan uji- $t$ satu pihak yaitu pihak kanan. Uji ini merupakan pembuktian dari hipotesis 1 yaitu untuk mengetahui apakah pencapaian akhir kemampuan pemahaman konsep matematika siswa kelas eksperimen lebih tinggi daripada kelas kontrol. Pada tabel $t$ menunjukkan bahwa $t_{\text {tabel }}$ dengan $\mathrm{dk}=61$ untuk uji satu pihak adalah 1,671, sedangkan didapat $t_{\text {hitung }}$ sebesar 3,66. Karena $t_{\text {hitung }} \geq t_{\text {tabel }}$ atau 3,66>1,671 maka $\mathrm{H}_{0}$ ditolak dan $\mathrm{H}_{1}$ diterima yaitu pencapaian akhir kemampuan pemahaman konsep matematika siswa kelas eksperimen lebih tinggi daripada siswa kelas kontrol. Dengan demikian pencapaian akhir kemampuan pemahaman konsep matematika siswa yang mendapatkan model pembelajaran think talk write lebih tinggi daripada siswa yang mendapatkan model pembelajaran ekspositori.

Sebagaimana data pretes, uji perbedaan dua rata-rata untuk data gain kemampuan pemahaman konsep matematika menggunakan uji-t. Perbedaannya adalah uji- $t$ yang digunakan yaitu uji satu pihak yaitu pihak kanan. Uji ini merupakan pembuktian dari hipotesis 2 yaitu untuk mengetahui apakah peningkatan kemampuan pemahaman konsep matematika siswa kelas eksperimen lebih tinggi daripada kelas kontrol. Pada tabel $t$ menunjukkan bahwa $t_{\text {tabel }}$ dengan $\mathrm{dk}=61$ untuk uji satu pihak adalah 1,671, sedangkan nilai $t_{\text {hitung }}$ didapat sebesar 2,84. Karena $t_{\text {hitung }} \geq t_{\text {tabel }}$ atau 2,84 > 1,671 maka $\mathrm{H}_{0}$ ditolak dan $\mathrm{H}_{1}$ diterima, sehingga diperoleh bahwa peningkatan kemampuan pemahaman konsep matematika siswa kelas eksperimen lebih tinggi daripada kelas kontrol. Maka kesimpulan adalah peningkatan kemampuan pemahaman konsep matematika 
siswa yang mendapatkan model pembelajaran think talk write, lebih tinggi siswa yang mendapatkan daripada siswa yang mendapatkan model pembelajaran ekspositori.

Hasil analisis data menunjukkan bahwa model pembelajaran memberikan pengaruh yang signifikan terhadap kemampuan pemahaman konsep matematika siswa. Hal ini disebabkan karena skor kemampuan pemahaman konsep matematikayang tinggi dipicu oleh model pembelajaran think talk writeyang dalam pelaksanaannya selalu memperhatikan langkah, prinsip, dan karakteristik pembelajaranthink talk write. Model pembelajaran think talk write difokuskan pada siswa agar dapat mengkonstruksi pengetahuannya secara diskusi kelompok dengan perantara lembar aktivitas siswa (LAS).

Tahap pengelompokkan, siswa diorganisasikan ke dalam kelompok yang masing-masing kelompok terdiri atas empat siswa berdasarkan kemampuan akademik yang beragam berdasarkan hasil tes kemampuan awal matematika yang telah dilakukan oleh peneliti sebelum penelitian. Pengelompokkan tersebut diharapkan siswa yang memiliki kemampuan awal matematika tinggi dapat membantu temannya yang memiliki kemampuan awal matematika rendah untuk menghubungkan konsep baru dengan konsep yang sudah dimiliki.

Tahap berpikir, guru mengarahkan siswa untuk membaca bahan bacaan dari buku paket dan kemudian menjawab pertanyaan-pertanyaan dengan merencanakan langkah-langkah penyelesaian masalah dalam LAS, misalnya: Apakah kamu memahami pertanyaan-pertanyaan dalam LAS? Bagaimana cara kamu menyelesaikan LAS? Siapa melakukan apa? Untuk tujuan apa kalian menginvestigasi LAS? Proses pemahaman konsep berlangsung dengan menjawab pertanyaan-pertanyaan dalam LAS.

Tahap berbicara, masing-masing anggota kelompok memberikan pendapatnya. Setiap kelompok melaksanakan rencana yang telah didiskusikan pada tahap sebelumnya. Siswa mengaitkan masalah dalam LAS dengan konsep yang sudah dimiliki. Pada tahap ini, siswa mengeksplor pengetahuannya dengan cara membaca, mengamati, dan mendiskusikan konsep-konsep yang berkaitan dengan materi yang dipelajari. Siswa menjawab pertanyaan-pertanyaan yang ada di LAS dengan cara diskusi kelompok yaitu menuliskan konsep yang berkaitan dengan materi yang dipelajari sesuai dengan pertanyaan dalam LAS. Siswa membangun pengetahuannya dengan menghubungkan konsep baru dengan konsep yang telah dimiliki.

Siswa menganalisis langkah-langkah yang telah mereka tempuh dalam upaya menyelesaikan masalah dan menyatukan informasi yang diperoleh pada tahap penyelidikan. Siswa melihat kembali hasil diskusi kelompok apakah sudah sesuai dengan perencanaan sebelumnya. Kemudian pada tahap presentasi, guru meminta salah satu perwakilan kelompok untuk mempresentasikan hasil diskusinya, sedangkan kelompok lain mengamati dan membandingkan dengan jawaban yang mereka peroleh. Guru membuka ruang tanya jawab terhadap kelompok-kelompok lain agar memberi tanggapannya terhadap jawaban. Hal ini diperlukan untuk mendalami lebih jauh tentang topik yang dikaji.

Tahap terakhir adalah tahap menulis. Pada tahap ini, siswa dan guru memeriksa ulang hasil pekerjaan masing-masing kelompok. Guru mengkonfirmasi mengenai konsep yang ditemukan dan masalah yang sudah diselesaikan. Siswa diharapkan dapat mempelajari kembali tentang hal-hal yang 
kurang dimengerti pada proses pembelajaran berlangsung dan membuat tulisan dari apa yang sudah didapat dalam pembelajaran. Siswa dan guru secara bersamasama membuat kesimpulan mengenai materi yang dipelajari.

\section{SIMPULAN DAN SARAN}

Berdasarkan hasil penelitian menunjukkan bahwa pertama, pencapaian akhir kemampuan pemahaman konsep matematika siswa yang mendapatkan model pembelajaran think talk write lebih tinggi daripada siswa yang mendapatkan model pembelajaran ekspositori. Kedua, peningkatan kemampuan pemahaman konsep matematika siswa yang mendapatkan model pembelajaran think talk write, lebih tinggi siswa yang mendapatkan daripada siswa yang mendapatkan model pembelajaran ekspositori. Dengan demikian model pembelajaran kooperatif tipe think talk write berpengaruh terhadap kemampuan pemahaman konsep matematika.

Dari kesimpulan yang diperoleh, peneliti memberikan saran untuk penelitian berikutnya agar menerapkan pembelajaran kooperatif tipe think talk write untuk meningkatkan kemampuan kognitif maupun afektif lain berdasarkan tinjauan dan materi yang berbeda agar dapat menambah pengetahuan untuk peneliti sendiri maupun untuk lingkungan. Selain itu, untuk para guru agar dapat memaksimalkan potensi siswanya dengan memberikan model pembelajaran kooperatif tipe think talk writeyang dapat mengembangkan kemampuan pemahaman konsep matematika di lingkungannya.

\section{DAFTAR RUJUKAN}

Auliya, Risma Nurul. (2013). Pengaruh Model Pembelajaran Kooperative Tipe CRH (Course, Review, Hurray) terhadap Kemampuan Pemahaman Konsep Matematis dan Kecemasan Matematika Siswa SMP. Tesis tidak diterbitkan. Bandung: Universitas Pendidikan Indonesia.

Hadi, Syamsul \& Novaliyosi. (2019). TIMSS Indonesia (Trends In International Mathematics And ScienceStudy). Prosiding Seminar Nasional \&Call For PapersProgram Studi Magister Pendidikan Matematika Universitas Siliwangi, 562-569.

Huiker, D. \& Laughlin, C. (1996). Talk Your Way into Writing In P. C Elliot and M. J. Kenney (Eds) 1996 Yearbook Communication in Mathematics, K-12 and Beyond. Virginia: NCTM.

Lestari, Eka Karunia \& Yudhanegera, M. Ridwan. (2015). Penelitian Pendidikan Matematika. Bandung: PT Refika Aditama.

National Council of Teacher Mathematics. (2000). Principles and Standards for School Mathematics. Reston, VA: NCTM.

PISA. (2015). Programme for International Student Assessment (PISA) Result from PISA 2015, (online), (https://www.oecd.org/pisa/PISA-2015Indonesia.pdf, diakses 28 November 2019).

Sumarmo. (2006). Pembelajaran Keterampilan Membaca Matematika pada Siswa Sekolah Menengah.Jurnal tidak diterbitkan. Bandung: Universitas Pendidikan Indonesia. 
Susanti, Elsa \& Salmini Safitri Syam. (2017). Peran Guru dalam Meningkatkan Literasi Matematika Siswa Indonesia. Seminar Matematika dan Pendidikan Matematika UNY, PM 30-35.

TIMSS. (2011). TIMSS 2011 International Result In Mathematics. US: TIMSS \& PILRS International Study Center.

Yamin, Martinis \& Bansu I. Ansari. (2012). Taktik Mengembangkan Kemampuan Individual Siswa. Jakarta: Referensi. 